\title{
Immunohistochemical Localization of Serotonin Transporter in the Adrenal Chromaffin Cells and Mast Cells of Mice
}

\author{
Taeko SaIto', Wakako Fusimoto', Haruko YANaSE ${ }^{1}$, Masahiko Watanabe ${ }^{2}$ and Toshihiko Iwanaga' \\ ${ }^{1}$ Laboratory of Anatomy, Graduate School of Veterinary Medicine, Sapporo 060-0818 and 'Department of Anatomy, Graduate School of \\ Medicine, Hokkaido University, Sapporo 060-8638, Japan
}

(Received 20 December 2002; and accepted 21 December 2002)

\begin{abstract}
Since the source and disposition of serotonin is still unclear in non-neuronal cells, we investigated the cellular expression of serotonin transporter (SERT) in mouse adrenal chromaffin cells, mast cells and enterochromaffin cells, all of which contain serotonin in their secretory granules. Immunohistochemistry using SERT antibody in the adrenal medulla demonstrated an intense immunoreactivity in the plasma membrane of adrenalin (A) cells, but not in that of noradrenalin (NA) cells. Electron-microscopically, the expression of SERT appeared to occur mainly on the lateral plasma membranes of A cells facing adjacent A cells. Peritoneal mast cells also displayed a selective immunoreactivity for SERT along the plasma membrane, although the intensity varied cell to cell. In the tongue, stomach, nasal mucosa and trachea, connective tissue-type mast cells were immunoreactive, but not mucosal-type mast cells. Gastrointestinal epithelial cells including enterochromaffin cells were free of the immunoreactivity. These findings suggest that SERT is involved in the uptake of serotonin in adrenal A cells and connective tissue-type mast cells.
\end{abstract}

Serotonin (5-hydroxytryptamine, $5 \mathrm{HT}$ ) is a bioactive monoamine with a broad distribution and multiple roles according to cell type and location. In the central nervous system, 5HT serves as a neurotransmitter or neuromodulator (19), except in the pineal gland where it acts as a precursor for the biosynthesis of melatonin (1). A large quantity of 5HT exists in non-neuronal organs such as the gastrointestinal tract, lung and urethra. Enterochromaffin cells and related cells are a major source of non-neuronal $5 \mathrm{HT}$, and the $5 \mathrm{HT}$ they released regulates peristalsis and fluid secretion in an endocrine and paracrine manner $(5,14,18,20)$. Significant quantities of $5 \mathrm{HT}$ are also released from platelets at sites of in-

Corresponding to: Dr. Toshihiko Iwanaga

Laboratory of Anatomy, Graduate School of Veterinary Medicine Hokkaido University, Kita-18 Nishi-9, Kita$\mathrm{ku}$, Sapporo 060-0818, Japan

TEL: +81-11-706-5187, FAX: +81-11-706-5190

e-mail: tiwanaga@vetmed.hokudai.ac.jp jury where $5 \mathrm{HT}$ functions as a potent vasoconstrictor $(9,26)$. Moreover, 5HT is co-released with histamine from mast cells to mediate inflammatory and allergic responses, at least in rodents (7).

In serotonergic neurons, serotonin transporter (SERT) is expressed at the presynaptic membrane where it is involved in the uptake of 5HT released into synaptic clefts $(3,4,17)$. In addition to SERT, serotonergic neurons express vesicular monoamine transporters (VMATs) for the intracellular transport and accumulation of $5 \mathrm{HT}$ in synaptic vesicles (11, 13). However, the VMATs that package catecholamines for release are less selective than the plasma membrane-type transporters.

In non-neuronal tissues, the uptake and metabolism of 5HT are not well understood. Therefore, we investigated, in the mouse, the cellular expression of SERT in three types of paraneuronal cells which contain 5HT in secretory granules: the adrenal chromaffin cells $(2,6,30)$, mast cells (7) and enterochromaffin cells (18). Since the cellular expression of 
SERT has already been reported in the rat adrenal medulla (27), we examined the subcellular localization of SERT in the adrenal gland of mice using electron microscopy.

\section{MATERIALS AND METHODS}

All experiments using animals were performed according to the Guidelines for Animal Experimentation, Graduate School of Veterinary Medicine, Hokkaido University.

Antibody and Western blot analysis. Polyclonal antibody to mouse SERT was raised against the $\mathrm{N}$-terminus of amino acid residues 1-77 (GenBank, AF013604), which is predicted to be cytoplasmic. The polypeptide was expressed as glutathione $\mathrm{S}$ transferase (GST) fusion protein using pGEX4T-2 plasmid vector (Pharmacia Biotech AB, Uppsala, Sweden). The fusion protein was purified with glutathione-Sepharose 4B (Pharmacia), emulsified with Freund's complete adjuvant (Difco, Detroit, MI), and injected subcutaneously into a female New Zealand White rabbit at intervals of 2 weeks. Two weeks after the sixth injection, affinity-purified antibodies were prepared, first using Protein G-Sepharose (Pharmacia) and then using antigen peptides coupled to CNBr-activated Sepharose 4B (Pharmacia). For the preparation of affinity media, polypeptide devoid of GST was obtained by elution of cleaved polypeptide following in-column thrombin digestion of fusion proteins bound to glutathione-Sepharose.

The adrenal gland and peritoneal mast cells from adult male ddY mice (about 8 weeks-old; Japan SLC, Hamamatsu, Japan) were used for an immunoblot analysis. The adrenal gland was snap-frozen in liquid nitrogen, and homogenized in an icecold $50 \mathrm{mM}$ Tris- $\mathrm{HCl}$ buffer (pH 7.5) containing 10 $\mathrm{mM}$ ethylenediamine-tetraacetic acid (EDTA), 1 $\mathrm{mM}$ phenylmethylsulfonyl fluoride (PMSF) and 1\% Triton X-100 for $30 \mathrm{~min}$. The samples were centrifuged $\left(10,000 \mathrm{~g}, 4{ }^{\circ} \mathrm{C}, 2 \mathrm{~min}\right)$, and the supernatant was collected. To obtain materials for mast cells, physiological saline $(5 \mathrm{~mL})$ was injected into the abdominal cavity of mice under anesthesia with pentobarbital sodium, and then collected $5 \mathrm{~min}$ after the injection. Peritoneal free cells containing mast cells were suspended after centrifugation, and solubilized with the buffer mentioned above. The solubilized proteins from the adrenal gland and peritoneal cells were subjected to $12 \%$ sodium dodecyl sulfate-polyacrylamide gel electrophoresis (SDS-PAGE) under reducing and non-reducing conditions. The proteins were then transferred to a nitrocellulose membrane (Hybond-P; Amersham, Buckinghamshire, England) and incubated with affinity-purified antibody against SERT $(5 \mu \mathrm{g} / \mathrm{mL})$ diluted in $0.01 \mathrm{M}$ phosphate-buffered saline (PBS, pH 7.4) containing $0.05 \%$ Tween 20 for $1 \mathrm{~h}$. The bound antibody was visualized using peroxidase-labeled goat-rabbit IgG (Bio-Rad, Hercules, CA) and an enhanced chemiluminescence (ECL) system (Amersham) according to the manufacturer's directions.

Immunohistochemistry. Adult male ddY mice were deeply anesthetized with an intraperitoneal injection of pentobarbital sodium and perfused via the left atrium with physiological saline followed by $4 \%$ paraformaldehyde in $0.1 \mathrm{M}$ phosphate buffer, $\mathrm{pH}$ 7.4. The adrenal gland, tongue, stomach, jejunum, nasal septum and trachea were removed, and immersed in the same fixative for an additional $6 \mathrm{~h}$. For mast cells, physiological saline containing peritoneal free cells was centrifuged, pelletized and fixed by gentle addition of a $4 \%$ paraformaldehyde fixative for $6 \mathrm{~h}$.

After being dipped in a $30 \%$ sucrose solution overnight at $4{ }^{\circ} \mathrm{C}$, all tissues were embedded in Tissue-Tec O. C. T. compound (Sakura Finetechnical, Tokyo, Japan), and quickly frozen in liquid nitrogen. Frozen sections, $5 \mu \mathrm{m}$ thick, were cut in a cryostat and mounted on poly-L-lysine-coated glass slides. They were pretreated with $0.3 \%$ Triton $\mathrm{X}$ 100 -containing PBS for $1 \mathrm{~h}$, and with $0.03 \% \mathrm{H}_{2} \mathrm{O}_{2}$ in methanol for the inhibition of endogenous peroxidase activity. After treatment with normal goat serum for $30 \mathrm{~min}$, the sections were incubated overnight at room temperature with rabbit polyclonal antibody against SERT at a concentration of $2 \mathrm{mg} / \mathrm{mL}$. The sections were then incubated with biotinylated goat anti-rabbit immunoglobulins and the streptavidin-peroxidase complex (Histofine kit; Nichirei, Tokyo, Japan). The antigen-antibody reaction was visualized by incubation in $0.05 \mathrm{M}$ Tris$\mathrm{HCl}$ buffer (pH 7.6) containing 0.01\% 3,3'-diaminobenzidine (DAB) and $0.001 \% \mathrm{H}_{2} \mathrm{O}_{2}$.

Immuno-electron microscopy. For immuno-electron microscopy, tissues were processed using a preembedding silver-intensified immunogold method. Paraformaldehyde-fixed cryostat sections were incubated with antibody against SERT (diluted at 2 $\mathrm{mg} / \mathrm{mL}$ with $0.1 \%$ bovine serum albumin-PBS), and subsequently reacted with goat anti-rabbit IgG covalently linked to $1.4 \mathrm{~nm}$ gold particles (BBInterna- 
tional, Golden Gate, England). Stained and silverintensified sections were osmificated, dehydrated, and embedded in Epon 812 (Nissin EM, Tokyo, Japan). Ultrathin sections were prepared and stained with an aqueous solution of $2 \%$ uranyl acetate for observation under an electron microscope (JEM100SX; JEOL, Tokyo, Japan).

In situ hybridization. Two non-overlapping antisense oligonucleotides were used for in situ hybridization. They were complementary to nucleotide residues $96^{-}$ 140 (ccacaccagcagacaaggcagagcctggacaaatatccaatgggt) and 1401-1445 (tcatcgtggtcatcacttgcatcttgggatccctgctcacactga) of mouse SERT mRNA (GenBank No. AF013604) (8). These oligonucleotides were labeled with ${ }^{35} \mathrm{~S}$-dATP, using terminal deoxynucleotidyl transferase (Promega, Madison, WI) at a specific activity of $0.5 \times 10^{9} \mathrm{dpm} / \mu \mathrm{g}$ DNA.

After sacrifice with a lethal dose of pentobarbital, the adrenal gland was quickly removed from adult ddY mice. Materials for mast cells were obtained as mentioned above. Fresh frozen sections, $10-14 \mu \mathrm{m}$ thick, were prepared and mounted on glass slides precoated with 3-amino-propyltriethoxysilane. They were fixed with $4 \%$ paraformaldehyde for $15 \mathrm{~min}$ and acetylated for $10 \mathrm{~min}$ with $0.25 \%$ acetic anhydride in $0.1 \mathrm{M}$ triethanolamine- $\mathrm{HCl}(\mathrm{pH} 8.0)$.

The sections were prehybridized for $2 \mathrm{~h}$ in a buffer containing $50 \%$ formamide, $0.1 \mathrm{M}$ Tris- $\mathrm{HCl}$ $(\mathrm{pH} 7.5), 4 \times \mathrm{SSC}(1 \times \mathrm{SSC} ; 150 \mathrm{mM} \mathrm{NaCl}$ and 15 $\mathrm{mM}$ sodium citrate), $0.02 \%$ Ficoll, $0.02 \%$ polyvinylpyrrolidone, $0.02 \%$ bovine serum albumin, 0.6 $\mathrm{M} \mathrm{NaCl}, 0.25 \%$ sodium dodecyl sulfate, $200 \mu \mathrm{g} / \mathrm{mL}$ of tRNA, $1 \mathrm{mM}$ EDTA and $10 \%$ dextran sulfate. Hybridization was performed at $42^{\circ} \mathrm{C}$ for $10 \mathrm{~h}$ in the hybridization buffer supplemented with 10,000 $\mathrm{cpm} / \mu \mathrm{L}$ of ${ }^{35} \mathrm{~S}$-labeled oligonucleotide probes. The glass slides were washed at room temperature for 30 min in $2 \times \mathrm{SSC}$ containing $0.1 \%$ sarkosyl and twice at $55^{\circ} \mathrm{C}$ for $40 \mathrm{~min}$ in $0.1 \times \mathrm{SSC}$ containing $0.1 \%$ sarkosyl. The sections were dipped in Kodak NTB2 nuclear tract emulsion and exposed for one month.

\section{RESULTS}

\section{Immunoblotting}

Polyclonal antibody against mouse SERT was raised in a rabbit and affinity-purified. Immunoblot analysis using the antibody revealed one major band at approximately $31 \mathrm{kDa}$ in extracts of the adrenal gland and in peritoneal free cells including mast cells, although the adrenal gland extracts contained less intense bands with different molecular sizes (Fig. 1).
There was no significant difference between reducing and non-reducing conditions (data not shown).

\section{Immunohistochemistry}

Immunostaining using the SERT antibody demonstrated intense immunoreactivity in the adrenal medulla and mast cells, but not in epithelial cells of the stomach and intestine, including enterochromaffin cells.

The immunoreactivity for SERT was preferentially localized to the plasma membrane of adrenal medullary cells but not all chromaffin cells. When we tried to identify SERT-positive cells on the basis of the fact that noradrenalin (NA) cells radiate more intense fluorescence than adrenalin (A) cells under a fluorescence microscope (Fig. 2a), we found A cells to be selectively immunoreactive for SERT (Fig. 2b).

Electron-microscopically, an intense expression of SERT immunoreactivity, visible as an accumulation of gold particles, was detected on the cytoplasmic membranes of A cells facing adjacent A cells (Fig. 6). The gold particles appeared to be localized on the inside of the plasma membrane (Fig. 6b). The plasma membrane on the vascular side showed no or weak immunoreactivity. The SERT immunoreactivity was undetectable on the plasma membrane which contacted with nerve terminals (Fig. 6a).

Sections containing peritoneal mast cells were prepared from pellets which collected free cells in the abdominal cavity, and stained with the SERT anti-
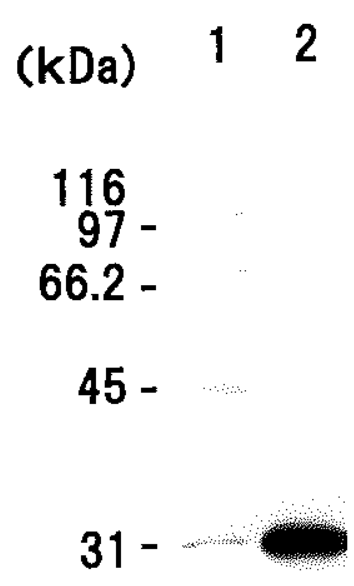

\section{$26.5-$}

Fig. 1 Western blot analysis of SERT in the adrenal gland (lane 1) and peritoneal mast cells (lane 2). The blotting pattern of immunoreactive SERT indicates the presence of a major band at $31 \mathrm{kDa}$ in both samples. 
body. Plasma membranes of large granular cells were intensely and specifically immunoreactive, although the staining intensity differed cell to cell (Fig. 3b). All of the immunopositive cells were stained red violet with toluidine blue, indicating that they were mast cells (Fig. 3a). In the stomach, large mast cells present in the tela submucosa, tunica muscularis and serous membrane were immunoreactive with heavy labeling on the cell surface, but any mast cells in the lamina propria and epithelium were negative (Fig. 4). Similarly, mast cells in the lamina propria of the tongue, small in size, were negative, while large mast cells dispersed in the muscle layer were intensely positive (Fig. 5). In the nasal septum and trachea, mast cells within the epithelium and subepithelial lamina propria were negative, but those in the tela submucosa showed intense immunoreactivity on the plasma membrane (data not shown).
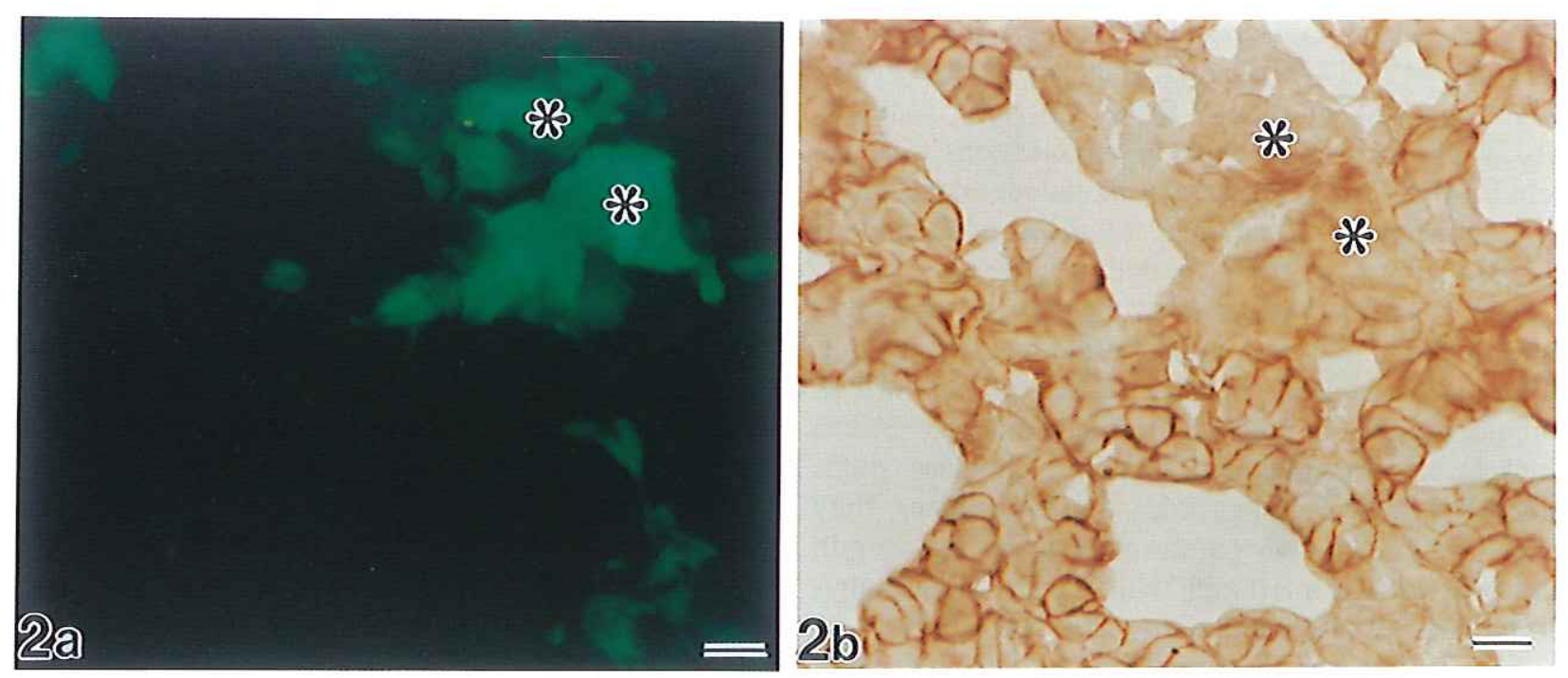

Fig. 2 Immunostaining of SERT and detection of noradrenalin (NA) fluorescence using a single section from the adrenal gland of a mouse. NA cells indicated by asterisks radiate fluorescence under a fluorescence microscope (a), and non-fluorescent adrenalin (A) cells are selectively immunoreactive for SERT (b). bar $=10 \mu \mathrm{m}$.

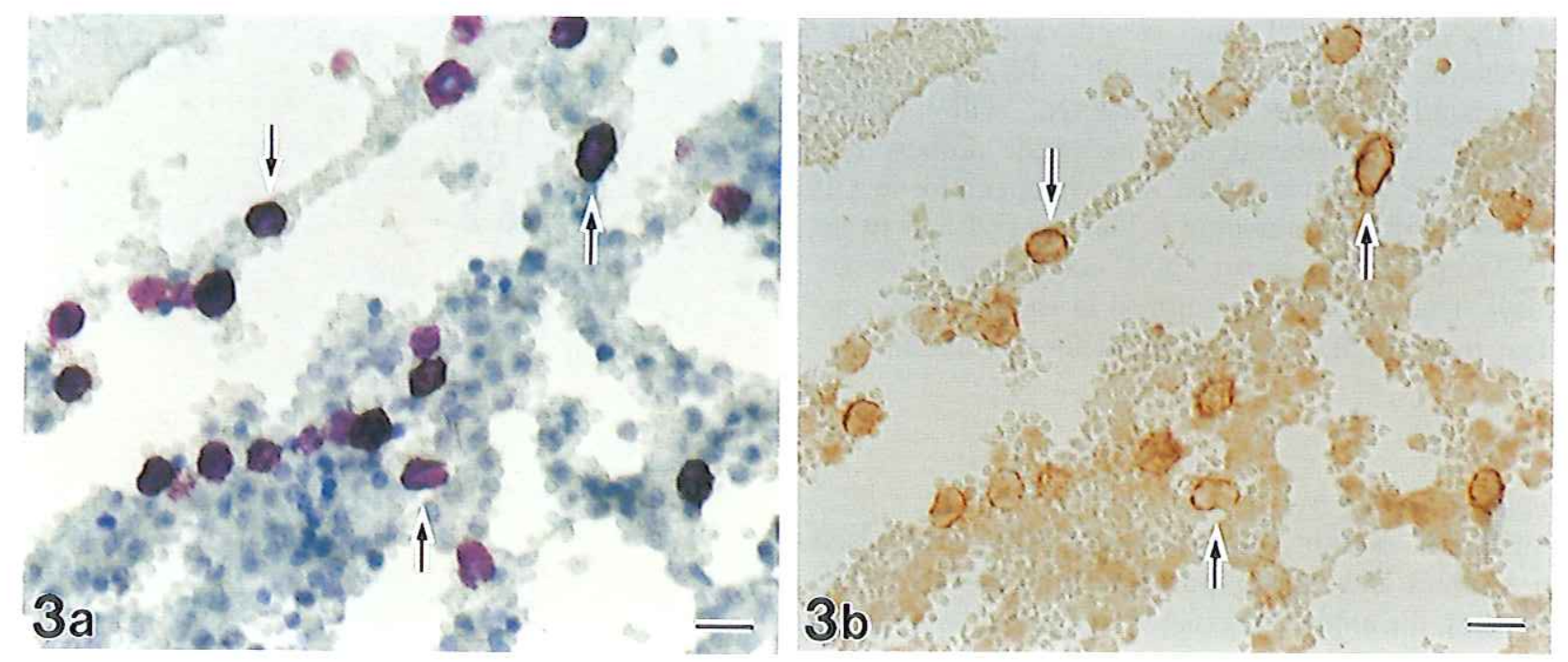

Fig. 3 Staining of SERT and toluidine blue using a single section containing peritoneal mast cells. Plasma membranes of large cells are immunoreactive with different intensities (b). All of the immunoreactive cells are stained with toluidine blue (a). Arrows indicate the same cells. bar $=20 \mu \mathrm{m}$. 


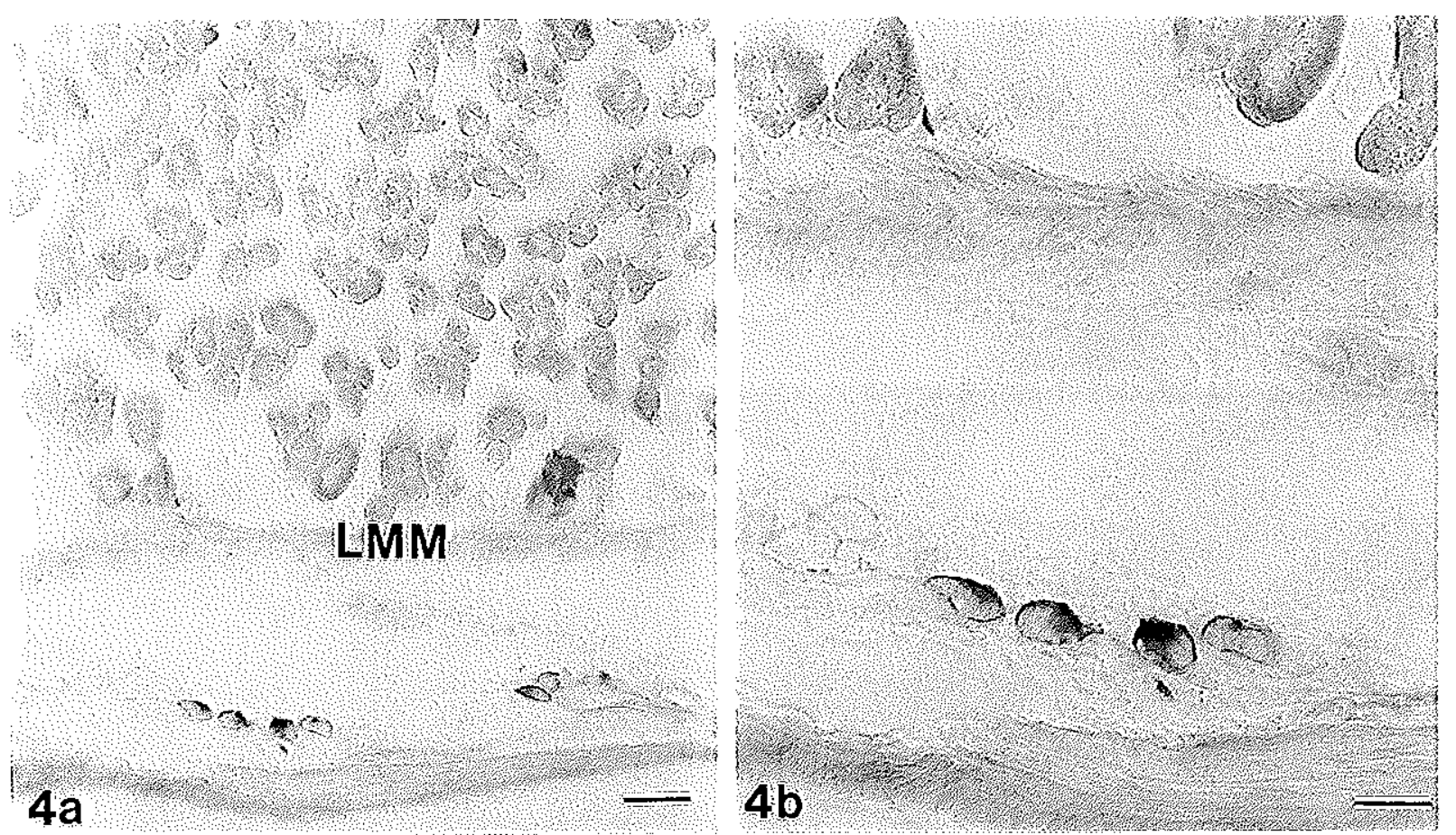

Fig. 4 Immunostaining of SERT in the stomach. Large mast cells in the tela submucosa are immunoreactive with intense labeling on the surface, while no immunoreactive cells are seen in the lamina propria over the lamina muscularis mucosae (LMM). Fig. $4 \mathrm{~b}$ is a higher magnification of Fig. 4a. bars $=40 \mu \mathrm{m}$ (a), $20 \mu \mathrm{m}$ (b).
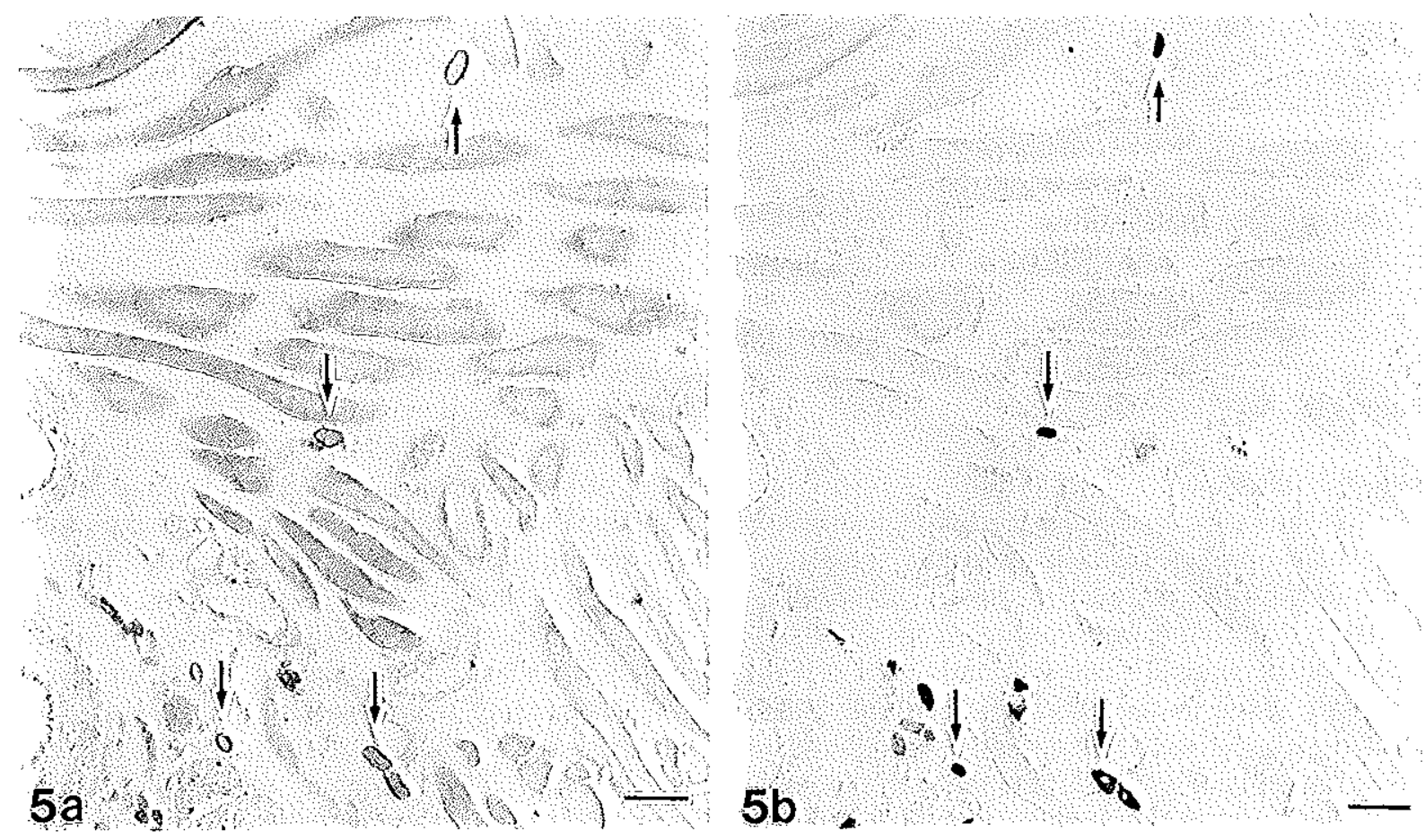

Fig. 5 Immunostaining of SERT in the tongue. Plasma membranes of mast cells in the muscle layer are intensely immunoreactive (a). Toluidine blue staining (b) on an adjacent section ( $5 \mu \mathrm{m}$ in thickness) shows that all of the SERTimmunoreactive cells are mast cells. Arrows indicate the same cells. bar $=40 \mu \mathrm{m}$. 

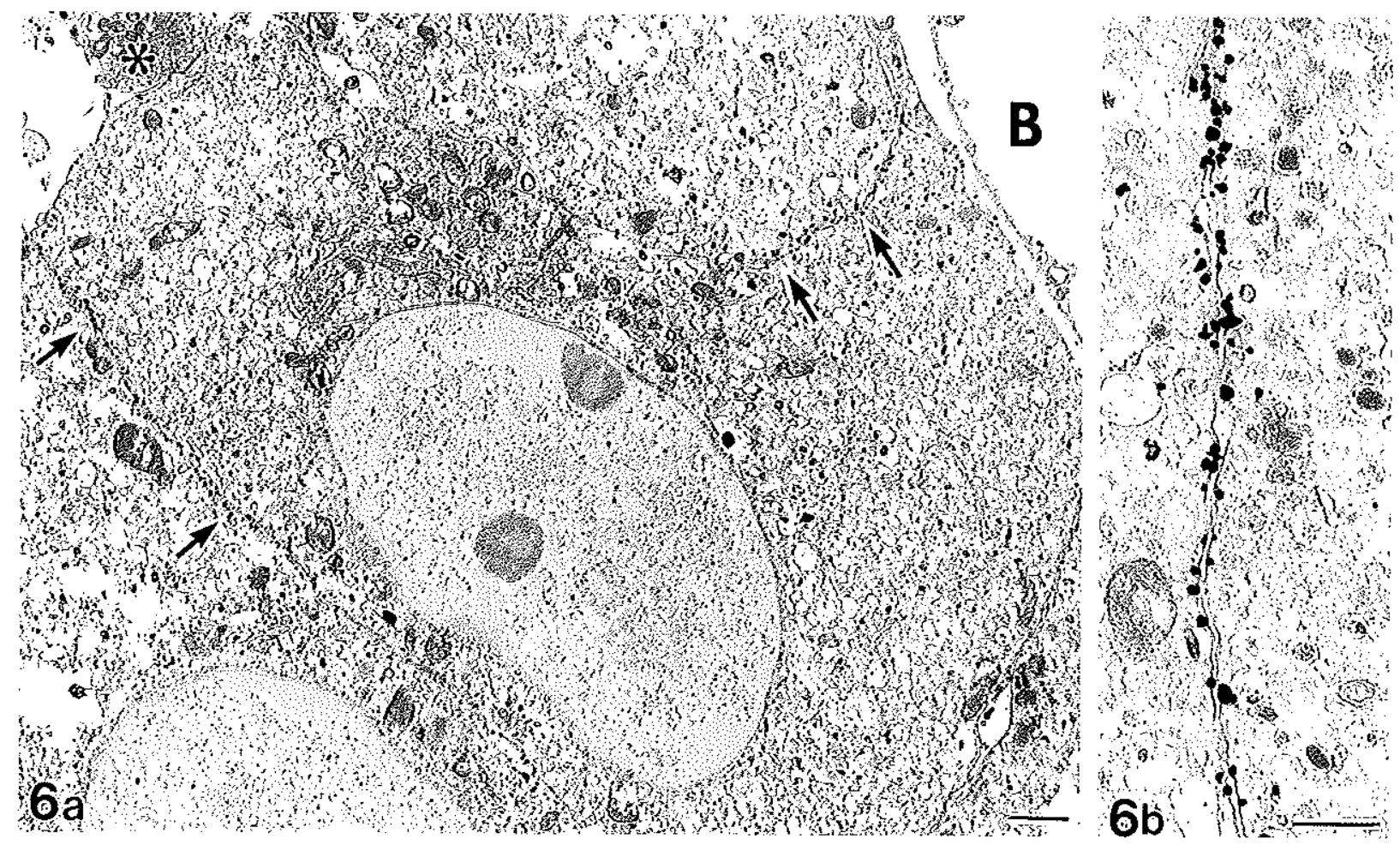

Fig. 6 Electron micrographs of SERT-immunoreactive adrenalin (A) cells. Intense expression of SERT appears on the lateral plasma membrane of A cells (arrows). The plasma membrane on the vascular side and in contact with a nerve terminal (asterisk) shows weak or no immunoreactivity. At a higher magnification of immunolabeled A cells (b), gold particles appear to be localized on the inside of the plasma membrane. B: blood vessels, bars $=1 \mu \mathrm{m}$ (a), 0.5 $\mu \mathrm{m}$ (b).

By immuno-electron microscopy, immunogold particles for SERT were found to be deposited on the plasma membrane of peritoneal mast cells (Fig. 7a, b). Intensely labeled cells contained many comparatively small granules, while weakly positive or negative mast cells possessed a small number of large granules which tended to be low in electron density (Fig. 7c).

\section{In situ hybridization}

In situ hybridization analysis using two non-overlapping antisense probes detected consistent signals for SERT mRNA in the adrenal medulla. The specificity of the hybridization was confirmed by the disappearance of the signals when an excess dose of cold probes was added to the hybridization fluid. In the adrenal gland, the mRNA expression was found in most chromaffin cells, but clusters of small chromaffin cells scattered in the medulla lacked the signals (Fig. 8a, b). Hybridization on sections containing peritoneal mast cells demonstrated selective expression of SERT mRNA in some large cells, although the frequency of occurrence of labeled cells was low
(Fig. 8c).

\section{DISCUSSION}

The present Western blot analysis using the SERT antibody demonstrated a single and a major immunoreactive band positioned at around $31 \mathrm{kDa}$ in the samples from peritoneal cells and the adrenal gland, respectively. SERT cDNAs were cloned from the brain of humans $(21,22,25)$, rats (23) and mice (8), and shown to translate a polypeptide composed of 630 amino acid residues with a calculated molecular weight of $\sim 70 \mathrm{kDa}$. Early investigations using photoaffinity labeling and radiation inactivation suggested that the human platelet SERT consists of several subunits with relative molecular masses in the range of $30^{-} 86 \mathrm{kDa}$ (15). In Western blotting of human brain, SERT proteins appeared as a single band of $31 \mathrm{kDa}(16)$ which corresponded to the immunoreactive band detected in the present study.

The present histochemical study revealed the localization of SERT in A cells of the mouse adrenal gland with both immunohistochemistry and in situ 

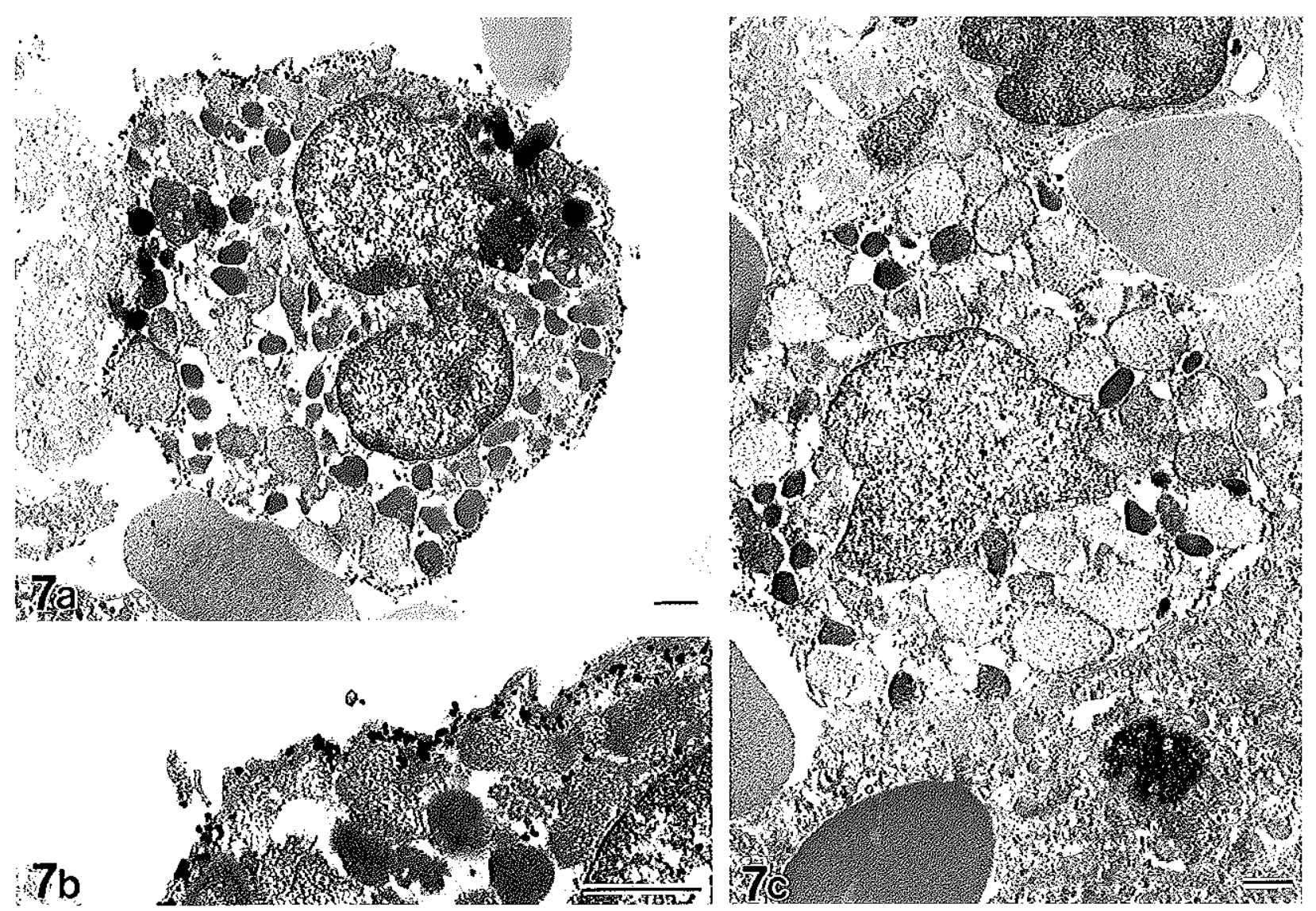

Fig. 7 Immuno-electron micrographs of peritoneal mast cells. Immunogold particles for SERT are densely distributed along the plasma membrane of a mast cell which contains many small granules (a). Fig. $7 \mathrm{~b}$ is a higher magnification of the cell shown in Fig. 7a. A peritoneal mast cell containing large pale granules is weakly immunoreactive (c). bar $=1 \mu \mathrm{m}$.

hybridization. A previous immunohistochemical study using rat adrenal gland reported that SERT existed on the plasma membrane of A cells but the plasma membrane facing sinusoids or the cortex lacked SERT immunoreactivity at a light microscopic level (27). The present staining result obtained from the mouse is in agreement with the finding in the rat. Furthermore, we revealed in detail the localization of SERT using immuno-electron microscopy: the intense expression of SERT was restricted to the lateral cell membrane which faced adjacent A cells, while other regions including junctions with nerve terminals lacked the immunoreactivity. Previous studies have reported that 5HT immunoreactivity in the rat adrenal medulla is confined to the A cells (30). Schroeter et al. (27) demonstrated a correspondence of SERT- and 5HTimmunoreactivities in the rat adrenal gland. Therefore, it is likely that only A cells release 5HT and recycle it by means of SERT. Since treatment with the
L-tryptophan hydroxylase (TPH) inhibitor $\mathrm{H} 22 / 54$ resulted in no change in the level of $5 \mathrm{HT}$ in the adrenal gland, and because the administration of 5hydroxytryptophan led to a marked increase in the level (30), it is suggested that 5HT contained in A cells is derived from circulating $5 \mathrm{HT}$ and/or 5-hydroxytryptophan. Uptake of circulating 5HT by A cells is supported by the lack of immunoreactivity for TPH, the rate-limiting enzyme in the 5HT biosynthetic pathway (27). However, we and also Schroeter et al. (27) failed to detect SERT on the plasma membrane of vascular side in A cells. Further evidence is needed of the involvement of SERT in the direct uptake of 5HT from the blood.

In the present study, we first revealed the expression of SERT on the plasma membrane of mast cells, and suggested that mast cells are able to uptake 5HT in tissue fluids. Since mast cells do not possess TPH for the synthesis of 5HT (24), it is considered that under normal conditions they can not 

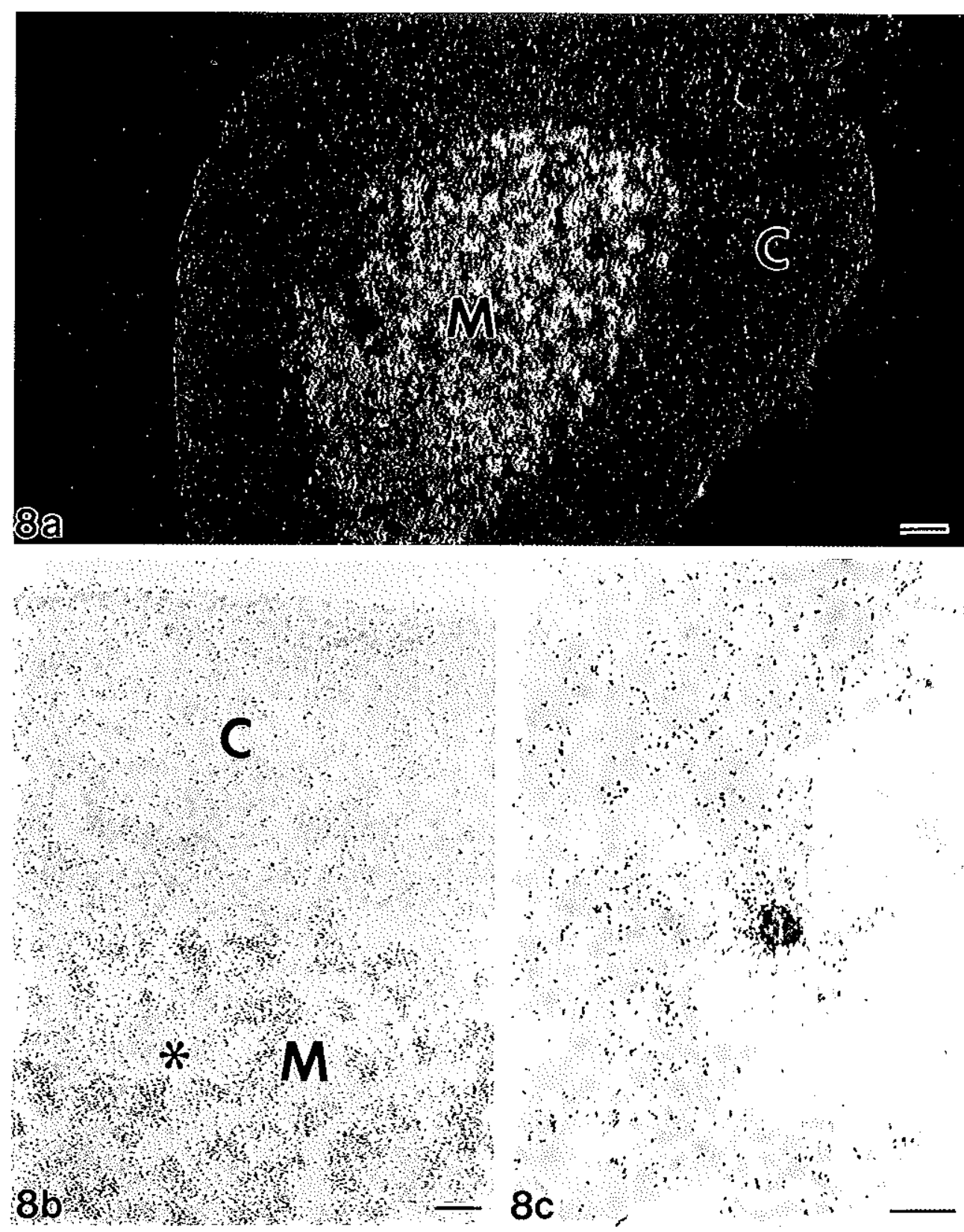

Fig. 8 In situ hybridization in the adrenal gland and peritoneal mast cells. A dark field image (a) shows intense expression of SERT mRNA only in the medulla (M). In a bright field image of the adrenal gland (b), signals for SERT mRNA are localized to medullary chromaffin cells with lack of the signals in some areas indicated by an asterisk. Hybridization on a section containing peritoneal free cells shows intense expression of mRNA in a large cell. C: cortex, bars $=50 \mu \mathrm{m}(\mathrm{a}), 20 \mu \mathrm{m}(\mathrm{b}$ and $\mathrm{c})$.

synthesize 5HT by themselves and instead incorporate circulating $5 \mathrm{HT}$. Generally, mast cells are classified as mucosal mast cells (MMCs) and connective tissue mast cells (CTMCs). The MMCs are distributed in the epithelium and lamina propria mucosae of the gut and respiratory tract, while the CTMCs are found in the tela submucosa of tubular organs, the connective tissue, and abdominal cavity. Both types of mast cells contain histamine, esterase and proteolytic enzymes, but only the former possess chondroitin sulfate, while only the latter contain heparin $(10,28,29,31)$. MMCs are smaller in cell size, and their granules are less numerous than those in CTMCs (12). Our staining results in mast cells in- 
dicate the predominant expression of SERT in CTMCs of the gut and respiratory organs. Mast cells in the ascites are extravasated mainly from the mesentery and peritoneum, and it is supposed that MMCs and CTMCs intermingle in the peritoneal cavity. In the present immunostaining of peritoneal mast cells, only large mast cells were intensely immunoreactive for SERT, with small mast cells negative or weakly positive. This staining result may be explained by the idea that the peritoneal mast cells are a mixture of MMCs and CTMCs.

Blood platelets contain 5HT in the cytoplasmic granules and uptake 5HT in blood via SERT expressed on the plasma membrane (22). Therefore, the SERT is shared by adrenal chromaffin cells, mast cells and platelets which are non-neuronal 5HT-containing cells. In contrast, enterochromaffin cells, which are a major site for de novo serotonin biosynthesis, express TPH and do not take up 5HT.

\section{REFERENCES}

1. Axelrod J. (1974) The pineal gland: a neurochemical transducer. Science 184, 1341-1348.

2. Berter A., Rosengren A.-M. and Rosengren E. (1960) In vivo uptake of dopamine and 5-hydroxytryptamin by adrenal medullary granules. Experientia 16, 418-419.

3. Blakely R. D., Berson H. E., Fremean R. T. Jr, Caron M. G., Peek M. M., Prince H. K. and Bradley C. C. (1991) Cloning and expression of a functional serotonin transporter from rat brain. Nature 354, 66-70.

4. Blakely R. D., De Felice L. J, and Hartzell H. C. (1994) Molecular physiology of norepinephrine and serotonin transporters. J. Exp. Biol. 196, 263-281.

5. Brown D. R. and Miller R. J. (1991) Neurohomonal control of fluid and electrolyte transport in intestinal mucosa. Handbook of Physiology, Sec. 6: The Gastrointestinal System, Vol. 4: Intestinal Absorption and Secretion, pp 527-589, American Physiological Society, Bethesda.

6. Brownfield M. S., Poft B. C. and Helzwarth M. A. (1985) Serotonin coexists with epinephrine in rat adrenal medullary cells. Neuroendocrinology 41, 230-236.

7. Carraway R. E., Cochrane D. E., Granier C., Kitabgi P., Leeman E. and Singer E. A. (1984) Parallel secretion of endogenous 5-hydroxytryptamine and histamine from mast cell stimulated by vasoactive peptides and compound $48 / 80 . \mathrm{Br}$. J. Pharmacol. 81, 227-229.

8. Chang A. S., Chang S. M., Starnes D. M., Schroeter S., Bauman A. L. and Blakely R. D. (1996) Cloning and expression of the mouse serotonin transporter. Mol. Brain Res. 43, 185192.

9. Cohen R. A. (1989) Interaction of 5-hydroxytryptamine with endothelial cells. The Peripheral Action of 5-hy'droxytryptamine. ed. Fozard, J. R., pp 182-200, Oxford Univ. Press, New York.

10. Crowle P. K. and Philips D. E. (1983) Characterisation of mast cells in Chediak-Higashi mice: light and electron microscopic studies of connective tissue and mucosal mast cells. Exp. Cell. Biol. 51, 130-139.

11. Edwards R. H. (1992) The transport of neurotransmitters into synaptic vesicles. Curn: Opin. Newrobiol. 2, 586-594

12. Enerback L. (1966) Mast cells in rat gastrointestinal mucosa. Effect of fixation. Acta Pathol. Microbiol. Scand. 66, 289302.

13. Erickson J. D., Eiden L. E. and Hofiman B. J. (1992) Expression cloning of a reserpine-sensitive vesicular monoamine transporter. Proc. Natl. Acad. Sci. USA 89, 10993-10997.

14. Gershon M. D., Dreyfus C. F., Pickel V. M., Joh T. H. and Reis D. J. (1977) Serotonergic neurons in the peripheral nervous system: identification in gut by immunohistochemical localization of tryptophan hydroxylase. Proc. Natl. Acad. Sci. USA 74, 3086-3089.

15. Graham D. and Langer S. Z. (1992) Advances in sodium-ion coupled biogenic amine transporters. Life Sci. 51, 631-645.

16. Gulesserian T., Engidawork E., Cairns N. and Lubec G. (2000) Increased protein levels of serotonin transporter in frontal cortex of patients with Down syndrome. Neurosci. Lett. 296, 53-57.

17. Hoffman B. J., Mezey E. and Brownstein M. J. (1991) Cloning of serotonin transporter affected by antidepressants. Science 254, 578-580.

18. Iwanaga T., Han H., Hoshi O., Kanazawa H., Adachi I. and Fujita T. (1994) Topographical relationship between serotonin-containing paraneurons and peptidergic neurons in the intestine and urethra. Biol. Signals 3, 259-270.

19. Jacobs B. L. and Azmitia E. C. (1992) Structure and function of the brain serotonin system. Physiol. Rev. 72, 165-229.

20. Legary C., Faudon M., Hery F. and Temaux J. P. (1983) 5HT metabolism in the intestinal wall of the rat. I. The mucosa. Newrochem. Int. 5, 721-727.

21. Lesch K.-P., Wolozin B. L., Estler H. C, Murphy D. L. and Riederer P. (1993) Isolation of a cDNA encoding the human brain serotonin transporter. J. Neural Transm. 91, 67-73.

22. Lesch K.-P., Wolozin B. L., Murphy D. L. and Riederer P. (1993) Primary structure of the human platelet serotonin uptake site: identify with the brain serotonin transporter. $J$. Netrrochem. 60, 2319-2322.

23. Mayser W., Betz H. and Schloss P. (1991) Isolation of cDNAs encoding a novel member of the neurotransmitter transporter gene family. FEBS Lett. 295, 203-206.

24. Ohtsuka H., Iwanaga T., Hasegawa H., Ichiyama A. and Fujita, T. (1991) Immunohistochemical localization of tryptophan hydroxylase and serotonin in the gastrointestinal tract of mice. Biomed. Res. 12, 131-142.

25. Ramamoorthy S., Bauman A. L., Moore K. R., Han H., YangFeng T., Chang A. S., Ganapathy V. and Blakely R. D. (1993) Antidepressant- and cocaine-sensitive human serotonin transporter: molecular cloning, expression, and chromosomal localization. Proc. Natl. Acad. Sci. USA 90, 2542-2546.

26. Rapport M. M., Green A. A. and Page I. H. (1948) Serum vasoconstrictor (serotonin) i. v. isolation and characterization. J. Biol. Chem. 176, 1243.

27. Schroeter S., Levey A. I. and Blakely R. D. (1997) Polarized expression of the antidepressant-sensitive serotonin transporter in epinephrine-synthesizing chromaffin cells of the rat adrenal gland. Mol. Cell. Netrosci. 9, 170-184.

28. Stevens R. L., Kate H. R., Seldin D. S. and Austen K. F. (1986) Biochemical characteristics distinguish subclasses of mammalian mast cells. Mast Cell Differentiation and Heterogeneity ed. Befus, A. D., Bienenstock, J. and Denburg, J., pp 183-204, Raven Press, New York.

29. Stevens R. L., Lee T. D. G, Seldin D. C., Austen K. F., Befus A. D. and Bienenstock J. (1986) Intestinal mucosal mast cells from rats infected with Nippostrongylus brasiliensis contain 
protease-resistant chondroitin sulfate di-B proteoglycans. $J$. Immunol. 137, 291-295.

30. Verhofstad A. A. J. and Jonsson G. (1983) Immunohistochemical and neurochemical evidence for the presence of serotonin in the adrenal medulla of the rat. Neuroscience $\mathbf{1 0}$,
$1443-1453$.

31. Yurt R. W., Leid R. W. Jr. and Austen K. F. (1977) Native heparin from rat peritoneal mast cell. J. Biol. Chem. 252, 518-521. 